\title{
Die Stellung der Physik und Meteorologie im Landwirtschaftsstudium
}

Einleitung ReNTscuLER: Ich erlaube mir, vorzuschlagen, die günstige Gelegenheit, dass sich hier in Wageningen eine grosse Zahl von Dozenten der Physik und Meteorologie an landwirtschaftlichen Hochschulen bzw. Fakultäten zusammen gefunden haben, dazu zu benützen, um kurz über die Stellung der Physik und Meteorologie im Landwirtschaftsstudium zu diskutieren. Ich habe aus den Vorlesungsverzeichnissen und durch Umfragen die folgende Tabelle über die Zahl der Unterrichtsstunden in diesen Fächern, zusammengestellt. Danach stehen für die Physik im Mittel im 1. Studienjahr 4 Wochenstunden, für die Meteorologie 1 Wochenstunde zur Verfügung. Allgemein besteht wohl zu Recht die Ansicht, dass sowohl der Physik als Grundlage der Naturwissenschaften und Technik als auch der Meteorologie ein gebührender Platz in der Grundausbildung der landwirtschaftlichen Studenten zukommt.

Auf die Frage, wie die Sachlage in anderen Ländern ist, wurden noch die folgenden Auskünfte gegeben :

Mrs. WoLFF : In Israël agricultural engineers are trained in two schools. One is the agricultural college which is a part from the university. The people it turns out go into farming or in research. The second institution is an engineering institute. Physics is not a special subject for them. They take courses in irrigation, soil conservation, machinery and such. Most students take machinery and many of them go into consulting work.

RENTSCHLER: (in Beantwortung einer Frage über den stoffmässigen Umfang des Physikunterrichtes).

Ich glaube nicht, dass man allzu viel von der modernen Physik weglassen darf, eher kann man auf die Akustik und auf manches aus der Optik verzichten. Der Landwirt soll einen Uberblick über das Gesamtgebiet der modernen Physik bekommen. Andererseits ist es ratsam, auch manche Dinge zu bringen, die normalerweise in der Anfangsvorlesung für Physiker nicht enthalen sind, z.B. einiges über Legierungen, physikalische Chemie usw.

SCHOFIELD. asks what do agricultural engineers do after their studies.

VAN $W_{\text {IJK }}$ : It is estimated at the agricultural university that $40 \%$ of the recently graduated agriculturists are concerned with research. After the meeting The Netherlands Society of Graduates in Agriculture was approached. They could not provide data pertaining to the recent years only but estimate that 30 per cent of the agriculturists from Wageningen graduated since 1945 are in research positions and stated that the percentage going into research has been rapidly increasing these last years. The remaining graduates are in various functions e.g. in consulting, teaching, or administrative positions.

RENTSCHLER: Viele werden Landwirtschaftslehrer und geben dann auch selbst Unterricht in Physik und Meteorologie, andere gehen in Forschungsinstitute oder in die Landwirtschaftsverwaltung.

DE VRrEs : It may be useful to explain that what the Germans and we call an "ingenieur" is not equivalent tot the English engineer, but rather to a man 


\section{UNTERRICHTSSTUNDEN DER PHYSIK UND METEOROLOGIE}

Landwirtschaftliche Fakultät oder Hochschule

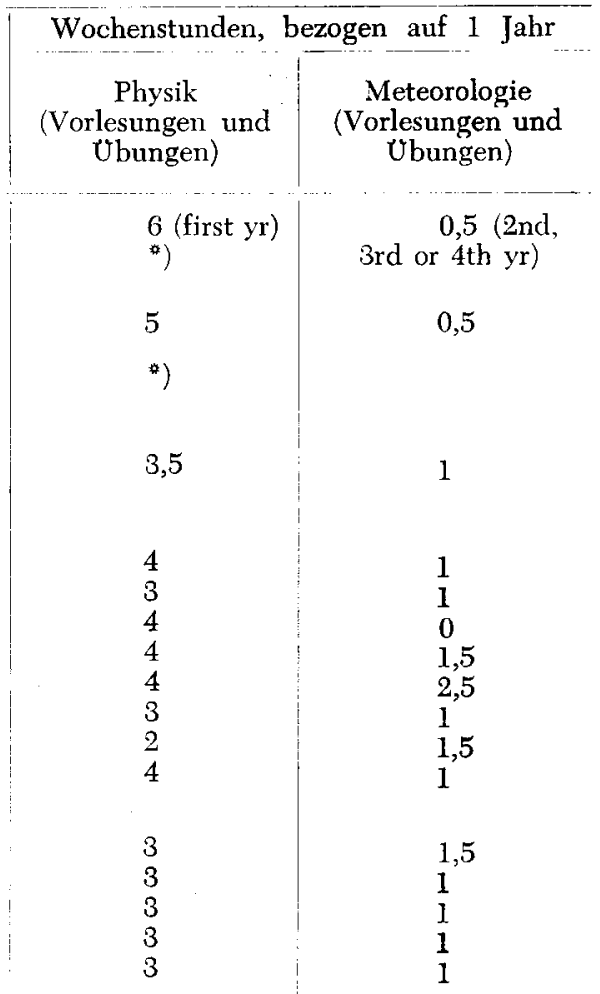

\section{Australien}

Belgien

Rijkslandbouwhogeschool Gent

Canada

Dänemark

Landbohøgskolen København

Deutschland (Bundesrepublik)

Techn. Univ. Berlin $\ldots \ldots \ldots \ldots \ldots \ldots \ldots$

Univ. Bonn .........................

Univ. Giessen ....................

Univ. Göttingen $\ldots \ldots \ldots \ldots \ldots \ldots \ldots \ldots$

T.H. Hannover . . . . . . . . . . . . . .

Landw. Hochschule Hohenheim .........

Univ. Kiel . . . . ................

T.H. München-Weihenstephan ............

D. Dem. Republik

Humbold-Univ. Berlin ...............

Univ. Halle $\ldots \ldots \ldots \ldots \ldots \ldots \ldots \ldots$

Univ. Jena $\ldots \ldots \ldots \ldots \ldots \ldots \ldots \ldots$

Univ. Leipzig $\ldots \ldots \ldots \ldots \ldots \ldots \ldots \ldots$

Univ. Rostock

Frankreich

Gr. Britannien

Israël

Jugoslawien

Belgrad

Novi Sad $\cdots \cdots \cdots \cdots \cdots \cdots$

Sarajevo $\ldots \ldots \ldots \ldots \ldots \ldots \ldots \ldots \ldots \ldots$

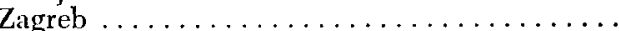

Ljubljana $\ldots \ldots \ldots \ldots \ldots \ldots \ldots \ldots \ldots$

Skoplje

Niederlande

Landbouwhogeschool Wageningen

Norwegen

Norges Landbrukshogskole As Vollebekk .....

Oesterreich

Hochschule f. Bodenkultur Wien ...........

Schweiz

E.T.H. Zürich ................

Ver. Staaten N. Amerika*)

Bachelor

Advanced degree $\ldots \ldots \ldots \ldots \ldots \ldots \ldots \ldots \ldots \ldots$
0

0

0

0

0

0

4

0,5

0,5

0

4

4

4

4

2

3

2

4

1 or 0

6

0

d) See discussion.

*) Data extracted from information provided by Prof. Don KIRKHAM, Ames, Iowa. The figures in the table are average figures. The programme of education varies considerably for different colleges. In several colleges no physics is required for a Bachelor's degree. 
having a mastersdegree in agricultural science. We would call the English engineer a technician.

Chrrds: Whilst one cannot generalize about departments of Agriculture throughout the United Kingdom, it may be useful if I outline experience in the University of Cambridge. Here we have an Ordinary Degree in Agriculture, a Diploma in Agriculture, and a Diploma in Agricultural Science. Students reading for the first enter the Department of Agriculture as soon as they enter the University and study husbandry and just so much of the sciences as are immediately necessary for the understanding of practical matters. In particular, no physics is taught in its own right, but only so much as is unavoidable in the teaching of soil science. About $60 \%$ of successful students take posts on farms, farm themselves, or in other ways enter into practical agriculture.

For the Diploma in Agriculture the student first spends two years in the University reading Natural Sciences which may seem to him, or to his advisers, to be most pertinent to Agriculture. During this time he has no formal contact with the Department of Agriculture. Successful candidates for Part 1 of the Tripos (an Honours qualification in general sciences) then spend two years in the Department of Agriculture learning the applications of their sciences. In principle such students could read physics in their first two years, but in practice very few do. Successful candidates for this Diploma commonly take up careers in agricultural administration and advisory work both at home and in the Commonwealth territories.

For the Diploma in Agricultural Science the student does not enter the Department of Agriculture until he has specialized in a particular science and has been classed in Part 2 of the Natural Sciences Tripos. He then spends one year learning the application of his science in particular, and other sciences with which he has been familiar because of his Part 1 reading, to a special branch of Agriculture, such as crop husbandry, animal husbandry, soil science, agricultural economics etc. It is intended that research workers, University teachers and other types of specalist should be drawn from this group, but in fact research workers are a rarety and University teachers, other than in general husbandry, are seldom produced. Research workers and specialist University teachers are almost invariably drawn from departments of pure science, and do not have any formal instruction in Agriculture before their appointments.

AsLYNG : In Denmark physics is taught 3 Semesters 3 hours including meteorology. Research is mainly done by non agriculturists.

Dr. Hallaire a communiqué les donnés suivants sur l'éducation en France.

Hallaire: Je dois préciser en premier lieu qu'en France, la formation d'un Ingénieur agronome comporte normalement deux étapes (après les études secondaires sanctionnées par le baccalauréat). Il faut y ajouter une troisième étape de spécialisation pour les chercheurs et les enseignants.

lère étape: Préparation du concours d'entrée à l'Ecole. Cette preparation dure en moyenne deux ans durant lesquelles on a 5 heures par semaine d'enseignement purement théorique de la physique. Total sur les 2 ans (35 semaines par an) $=350 \mathrm{~h}$.

2ème étape: A l'école elle-même (durée 2 ans). 


\begin{tabular}{|c|c|c|}
\hline & $\begin{array}{l}\text { PHYSIQUE } \\
\text { (Cours et travaux } \\
\text { pratiques) }\end{array}$ & METEOROLOGIE \\
\hline $\begin{array}{l}\text { a) Institut National Agronomique (Paris) } \ldots \ldots \\
\text { b) Ecoles nationales d'Agriculture } \\
\text { Grignon } \ldots \ldots \ldots \ldots \ldots \ldots \ldots \ldots \ldots \ldots \ldots \ldots \ldots\end{array}$ & $\begin{array}{l}30 \mathrm{~h} \\
35 \mathrm{~h}\end{array}$ & $15 \mathrm{~h}$ \\
\hline Montpellier $\ldots \ldots \ldots \ldots \ldots \ldots \ldots \ldots \ldots$ & 50 & $\mathrm{~h}$ \\
\hline $\begin{array}{l}\text { Rennes } \\
\text { Alger } \quad \ldots \ldots \ldots \ldots \ldots \ldots \ldots \ldots \ldots \ldots \ldots \ldots \ldots \ldots \ldots \ldots \ldots \ldots \ldots\end{array}$ & $\begin{array}{l}45 \mathrm{~h} \\
45 \mathrm{~h}\end{array}$ & $\begin{array}{l}15 \mathrm{~h} \\
18 \mathrm{~h}\end{array}$ \\
\hline $\begin{array}{l}\text { c) Ecole Nationale d'Horticulture (Versailles) ... } \\
\text { d) Ecoles privées (à titre d'exemple) ....... }\end{array}$ & 0 & $18 \mathrm{~h}$ \\
\hline 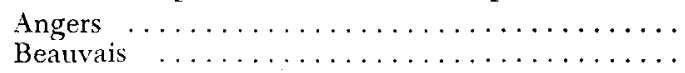 & $?$ & $\begin{array}{l}8 \mathrm{~h} \\
6 \mathrm{~h}\end{array}$ \\
\hline
\end{tabular}

N.B. Les heures comptées ici pour l'enseignement de la physique ne concernent pas la physique appliquée (Electrotechnique, hydrology, résistance des matériaux) qui est incluse dans le cours de "Génie rural" et comprend une soixantaine de leçons d'une heure. Il s'agit uniquement de la physique générale et plus particulièrement: thermodynamique, chimie physique, optique.

3ème étape: Spécialisation en vue de la recherche ou de l'enseignement.

a) Bème année d'études à l'Institut National Agronomique $\ldots \ldots \ldots \ldots \ldots \ldots \ldots \ldots$

b) éventuellement pour ceux qui se spécialisent dans la Météorologie et la Physique agricoles : certificats à l'Université des Sciences :

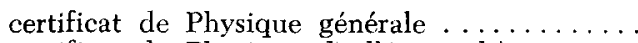

certificat de Physique de l'Atmosphère ......

\begin{tabular}{c|c}
$60 \mathrm{~h}$ & $15 \mathrm{~h}$ \\
& \\
$560 \mathrm{~h}$ & 0 \\
0 & $215 \mathrm{~h}$ \\
\hline
\end{tabular}

The following data conceming education in Canada were submitted by Dr. W. J. Staple after his return to Canada.

MacDonald College, Quebec.
1 th year
- 3 lectures, one 2-hr. laboratory per week
2nd year
- 3 lectures, one 2-hr. laboratory per week
3 rd \& 4th years - students majoring in agronomy, bacteriology or chemistry take biophysics one term, 2 lectures and one 4-hr. laboratory per week.
- students majoring in soil and plant chemistry and agricultural engineering take soil physics one term, 1 lecture and 1 laboratory per week.

Elementary meteorology is an elective of about 12 lectures. The amount of physics given varies from a minimum of 8 units to a maximum of 13 units distributed over 4 years. 


\section{University of Manitoba.}

Those entering with matriculation physics are not required to take additional physics in agricultural courses at university. Most agriculture students do not take meteorology. Students taking the soils option take a one-term course in wheather offered by the Geography department .

\section{University of Saskatchewan.}

Those entering agricultural college must have matriculation physicș. Further physics is not required in the general course but is taken in the 3rd of 4th years in many of the eleven special courses offered. Of 24 students graduating, 6 took no physics; 2 had a half class each; 7 had one full class; 2 had one and one-half classes; 2 had two classes; 4 had two and one-half classes; and one took three classes in physics. Each class consists of 3 lectures and 4 or 6 hours laboratory per week.

\section{University of Alberta.}

Those entering agricultural college must have matriculation physics. At present it is not compulsory for students to take further physics although many of them do. The Department of Soil Science encourages students to take one or more physics electives in senior years.

The curriculum is being revised and if new proposals are adopted one phyics course will be required for all students in the lst year. Those in Soil Science will probably be required to take more than this.

\section{Ontario Agricultural College.}

\begin{tabular}{|c|c|}
\hline 1st year & $\begin{array}{l}\text { - } 3 \text { lectures, one } 2 \text {-hr. laboratory each week, } \\
2 \text { terms ( } 26 \text { weeks) }\end{array}$ \\
\hline 2nd year & $\begin{array}{c}\text { - } 3 \text { lectures, one } 2 \text {-hr. laboratory each week, } \\
\text { 1th term (12 weeks) }\end{array}$ \\
\hline & $\begin{array}{l}\text { also } 2 \text { lectures, one } 2 \text {-hr. laboratory each } \\
\text { week, } 2 \text { nd term ( } 14 \text { weeks). }\end{array}$ \\
\hline 3 rd \& 4th year & $\begin{array}{l}\text { Practical options take no physics but Science } \\
\text { options take varying amounts. For example, } \\
\text { Agriculture engineers take applied mechanics, } \\
1 \text { lecture and } 2 \text {-hr. laboratory per week } 2 \\
\text { terms) and soil physics, } 2 \text { lectures and } 3 \text {-hr. } \\
\text { laboratory (2nd term) in their 3rd year. They } \\
\text { take the equivalent of } 3 \text { lectures per week in } \\
\text { the } 4 \text { th year. Those in Agricultural Science } \\
\text { take the equivalent of } 4 \text { lectures per week in } \\
\text { the 3rd year and } 6 \text { lectures and 6-hr. labora- } \\
\text { tory per week the } 4 \text { th year. }\end{array}$ \\
\hline
\end{tabular}

Mr. Prunster and Dr. de Vries have given the following additional information concerning Australia. 
The syllabus for the Course in Agriculture of the agricultural faculties of the following universities were examined:

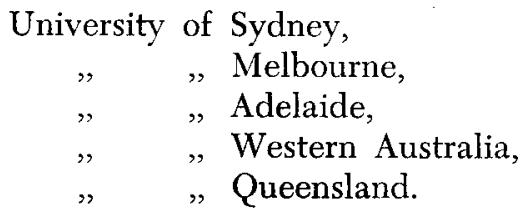

Physics courses, named as such, are taken in the first year of the study for Bachelor of Agricultural Science. They comprise three hours of lectures a week (Queensland, 2h) and three hours laboratory work a week during that year. The courses are to the level of the well-known text book: Analytical Experimental Physics by H. B. Lemon and M. Ference. (See for a classification of the course: the Handbook 1955, Faculties of Agricultural and Veterinary Science, University of Melbourne, p. 48).

Physics in subsequent years of the bachelor degree study is treated or applied in such courses as: Agriculture, Agricultural Chemistry, Biochemistry, Soil Science and Agricultural Engineering. The time devoted to physics is difficult to estimate. Professor TEAKLE of the University of Queensland estimates the total (including the physics course mentioned above) to a half year in the four year course.

Physics is not specifically mentioned in the courses for Master of Agriculture.

Meteorology (or rather, climatology) is treated as part of courses in Agriculture, Agronomy or Soil Science. The time devoted to Meteorology cannot be estimated.

SCHOFIELd : It is a very interesting discussion. Physics is important to all educations but it is particularly so for those going into research. 